\title{
LINKAGE TO THE S-LOCUS IN DIPLOID POTATOES
}

\author{
N. W. SIMMONDS \\ John Innes Institute, Hertford *
}

Received 29.xii.65

\section{INTRODUCTION}

THE cultivated diploid potatoes of the Andes have an oppositionalallele gametophytic type of incompatibility controlled by alleles at the $S$-locus; being outbreeders, they are frequently heterozygous for deleterious recessive genes, of which a considerable number has been studied (Dodds and Paxman, I 962; Simmonds, I 965). Few linkages in the cultivated potatoes are known and the present case is one of the few known instances of linkage to the $S$-locus. It first attracted attention in a predictable fashion-as a disturbance of normal monohybrid segregation followed by the observation that siblings of like genotype tended to be inter-incompatible.

\section{MATERIALS AND METHODS}

Two diploid clones $(2 n=2 x=24)$ from the Commonwealth Potato Collection were used. They were C.P.C. 2862 and 2863 , which were collected at Tota, Colombia, by Drs K. S. Dodds and G. J. Paxman in 1960, the former under the name "Pan de Dios", the latter as "Galletos Colorados". In appearance the two clones are rather similar but the former has round tubers and is rather infertile while the latter has elongated tubers and is highly seed-and pollen-fertile. The similarity is significant because, the clones have one $S$-allele and an uncommon recessive gene in common and are, with all reasonable certainty, closely related: they could be siblings.

Plants were assigned to incompatibility groups on the results of reciprocal pollinations with siblings, checked occasionally, when necessary, by cytological examinations of pollen tube growth. A few anomalous results caused by illegitimate growth of incompatible tubes were easily detected by comparisons of seed yields (John Innes Inst., 1961). One plant that must have been the product of illegitimate fertilisation in the previous generation was also identified.

\section{RESULTS}

(i) Genetical results

The recessive gene studied was droopy $(d r)$ which is expressed as an inability to control transpiration (Simmonds, I965; Waggoner and Simmonds, I 966 - physiological studies). Homozygotes are generally fairly viable and often fertile, despite a poor appearance. Droopy plants are taller and slimmer than normals and have smaller leaves; the first signs of droopiness can be detected in small seedlings and classification is generally excellent about 5 weeks after sowing the seed.

* Present address: Scottish Plant Breeding Station, Pentlandfield, Roslin, Midlothian, Scotland. 
The plants wilt during the day and this results in much tip scorching and premature leaf fall. The allele $d r$ is fully recessive and homozygous droopies breed true.

It is convenient to present the breeding results that follow in two parts: first, it is shown that, if the primary cross is represented as

$$
\begin{aligned}
& \text { C.P.C. } 2862 \times \text { C.P.C. } 2863 \\
& \frac{D r S_{1}}{d r S_{2}} \quad \frac{\operatorname{Dr} S_{1}}{d r S_{3}}
\end{aligned}
$$

then breeding tests of a sample of progeny show that only three $S$-alleles are present and provide direct evidence of linkage by classification at both loci; and, second, having proved the existence of linkage, it is

TABLE I

Analysis of the progeny of two diploid potatoes, C.P.C. $2862 \times$ C.P.C. 2863 ,

\begin{tabular}{|c|c|c|c|c|c|c|c|}
\hline $\begin{array}{l}\text { Non- } \\
\text { recomb. }\end{array}$ & \multicolumn{2}{|c|}{$\begin{array}{l}\text { Crossovers in } \\
\text { male }\end{array}$} & \multicolumn{2}{|c|}{$\begin{array}{l}\text { Crossovers in } \\
\text { both parents }\end{array}$} & \multicolumn{2}{|c|}{$\begin{array}{l}\text { Crossovers in } \\
\text { female }\end{array}$} & $\begin{array}{l}\text { Non- } \\
\text { recomb. }\end{array}$ \\
\hline 1 & 2 & 3 & 4 & 5 & 6 & 7 & 8 \\
\hline $\begin{array}{c}\operatorname{Dr} S_{1} \\
d r S_{3} \\
+ \\
16\end{array}$ & $\begin{array}{c}\operatorname{Dr} S_{1} \\
\operatorname{Dr} S_{3} \\
+ \\
\quad\end{array}$ & $\begin{array}{l}d r S_{2} \\
D r S_{3} \\
\quad+ \\
\quad 2\end{array}$ & $\begin{array}{c}\operatorname{Dr} S_{2} \\
D r S_{3} \\
\quad+ \\
\quad\end{array}$ & $\begin{array}{c}d r S_{1} \\
\operatorname{Dr} S_{8} \\
+ \\
0\end{array}$ & $\begin{array}{c}\text { Dr } S_{2} \\
d r S_{3} \\
+ \\
\quad\end{array}$ & $\begin{array}{c}d r S_{1} \\
d r S_{3} \\
d r o o p y \\
1\end{array}$ & $\begin{array}{c}d r S_{2} \\
d r S_{3} \\
d r o o p y \\
\quad 18\end{array}$ \\
\hline
\end{tabular}
$\operatorname{Dr} \mathrm{S}_{1} / \mathrm{dr} \mathrm{S}_{2} \times \operatorname{Dr} \mathrm{S}_{1} / \mathrm{dr} \mathrm{S}_{8}$

$$
\begin{aligned}
& \text { Recombination per cent. }=7 / 80=8 \cdot 8 \\
& \text { Family segegrations }\left\{\begin{array}{l}
2862 \times 2863-237+: 147 d r \\
2863 \times 2862-283+: 1 \text { i } 8 d r
\end{array}\right.
\end{aligned}
$$

shown that various observed biases and reciprocal differences in segregating families classified for droopy alone agree with theoretical expectations.

Results summarising formal evidence of linkage are given in table $I$. It should be noted that the $S$-allele numbers I, 2 and 3 are used here as a matter of convenience: their identity in terms of known $S$-alleles has not been investigated.

The results show that the 40 plants analysed represent seven crossover gametes, so the evidence for linkage is clear. Many entries in table I depend upon breeding tests as well as upon determination of $+/ d r$ phenotype and incompatibility group. The results need not be given in detail but are incorporated in table 3. It will be noted that, though droopies do not require a breeding test, normals do, since classes (1) (2) (5) and (3) (4) (6) are alike in phenotype and incompatibility but differ in constitution; the test is best made by crossing as males to compatible droopies, when quite small test progenies suffice for classification. 
The theoretical effects of linkage on the segregation of droopy are summarised in table 2. It will be seen that it leads to excess of either droopy or normal and that reciprocal crosses may agree or disagree. Four different types of disturbed segregation can be distinguished (tables 2 and 3 ).

\section{TABLE 2}

The effects of linkage to the $\mathrm{S}$-locus in the presence of three S-alleles; types of biased segregation and maximum likelihood estimates of $\mathrm{p}$ and $\mathrm{V}_{\mathrm{p}}$

\begin{tabular}{|c|c|c|}
\hline Type of data & $\begin{array}{l}\text { Recombination, } p \\
+a_{1}: d r a_{2}\end{array}$ & $V_{p}$ \\
\hline $\begin{array}{l}\text { A. } F_{2} \text { data } \\
\text { 1. Excess } d r \text { both ways } \\
\text { 2. }\left\{\begin{array}{l}\text { Excess } d r \text { one way } \\
\text { Excess }+ \text { in recip. }\end{array}\right\} \\
\text { 3. Excess }+ \text { both ways }\}\end{array}$ & $\begin{array}{l}\frac{a_{1}-a_{2}}{a_{1}+a_{2}} \\
\frac{2 a_{2}}{a_{1}+a_{2}}\end{array}$ & $\frac{\frac{(\mathrm{I}+p)(\mathrm{I}-p)}{n}}{\frac{p(2-p)}{n}}$ \\
\hline $\begin{array}{l}\text { B. Backcross data } \\
\text { I. No bias with }+ \text { female, } \\
\text { excess } d r \text { in recip. } \\
\text { 2. No bias with }+ \text { female, } \\
\text { excess }+ \text { in recip. }\end{array}$ & $\begin{array}{l}\frac{a_{1}}{a_{1}+a_{2}} \\
\frac{a_{2}}{a_{1}+a_{2}}\end{array}$ & $\begin{array}{l}\frac{p(1-p)}{n} \\
\frac{p(1-p)}{n}\end{array}$ \\
\hline
\end{tabular}

TABLE 3

Segregations for the gene droopy in diploid potatoes.

Classes in excess in bold face type

\begin{tabular}{|c|c|c|c|c|c|}
\hline \multirow{2}{*}{$\begin{array}{l}\text { Type of cross } \\
\text { (see table 2) }\end{array}$} & \multicolumn{2}{|c|}{$\begin{array}{c}\text { Observed } \\
\text { segregation }\end{array}$} & \multirow{2}{*}{$\begin{array}{c}x^{2} \\
\text { [d.f. }]\end{array}$} & \multirow{2}{*}{$\begin{array}{c}p \pm S_{p} \\
\text { per cent. }\end{array}$} & \multirow{2}{*}{$\begin{array}{c}\text { Range of } p \\
\text { between families }\end{array}$} \\
\hline & + & $d r$ & & & \\
\hline $\begin{array}{l}F_{2} \text { excess } d r \\
F_{2} \text { excess }+ \\
\text { Backcross }+\times d r . \\
\text { no bias }\end{array}$ & $\begin{array}{l}792 \\
93^{6} \\
459\end{array}$ & $\begin{array}{l}469 \\
108 \\
474\end{array}$ & $\begin{array}{l}\text { het. } 20 \cdot 8[5] \\
\text { het. } 43 \cdot 9[5] \\
\text { het. I } 8 \cdot 2[23] \\
\text { dev. } 0 \cdot 2[1]\end{array}$ & $\begin{array}{c}25 \cdot 6 \pm 2 \cdot 7 \\
20 \cdot 7 \pm 1 \cdot 9 \\
-\end{array}$ & $\begin{array}{c}6 \cdot 6-41 \cdot 1 \\
2 \cdot 2-33 \cdot 7 \\
-\end{array}$ \\
\hline Backcross $d r \times+$, & 86 & $2 \times 4$ & het. $45 \cdot 9[\mathrm{I}]$ & $28 \cdot 7 \pm 2 \cdot 6$ & $8 \cdot 5-44 \cdot I$ \\
\hline $\begin{array}{l}\text { excess } d r \\
\text { Backcross } d r \times+, \\
\text { excess }+\end{array}$ & rogo & I 99 & het. $45 \cdot 2[35]$ & $15.4 \pm 1 \cdot 0$ & $4 \cdot 2-27 \cdot 3$ \\
\hline
\end{tabular}

Breeding results are given in table 3 in which are included data from the families used to test the constitutions of $F_{1}$ plants (table I). Pedigrees were, of course, scrutinised carefully throughout; no significant anomalies appeared. All four expected types of biased segregation were detected, together with undisturbed backcross ratios (from 
homozygous droopies as males); but (as also expected) neither undisturbed $F_{2}$ ratios nor undisturbed backcross ratios from families having heterozygous male parents appeared.

TABLE 4

Segregation of the gene droopy in potatoes-formal comparisons of reciprocals. Classes in excess in bold face

\begin{tabular}{|c|c|c|c|c|c|}
\hline \multirow{3}{*}{ Type of segregation } & \multirow{3}{*}{$\begin{array}{c}\text { Family } \\
\text { pairs }\end{array}$} & \multicolumn{4}{|c|}{ Observed segregations } \\
\hline & & \multicolumn{2}{|c|}{ I } & \multicolumn{2}{|c|}{2} \\
\hline & & + & $d r$ & + & $d r$ \\
\hline $\begin{array}{l}F_{2} \text {, excess } d r \text { both ways } \\
F_{2} \text {, excess }+ \text { both ways } \\
F_{2} \text {, reciprocal difference } \\
\text { Backcross, excess }+ \text { one way } \\
\text { Backcross, excess } d r \text { one way }\end{array}$ & $\begin{array}{r}2 \\
1 \\
2 \\
15 \\
2\end{array}$ & $\begin{array}{r}300 \\
\times 77 \\
113 \\
425 \\
86\end{array}$ & $\begin{array}{r}203 \\
2 \\
73 \\
94 \\
214\end{array}$ & $\begin{array}{r}276 \\
44 \\
192 \\
241 \\
42\end{array}$ & $\begin{array}{r}r 50 \\
6 \\
8 \\
245 \\
36\end{array}$ \\
\hline
\end{tabular}

\section{TABLE 5}

The results of outcrossing droopy plants to unrelated normals. Above-sib-and inter-crosses of $+/ \mathrm{dr}$ heterozygotes having no or one S-allele in common; below-backcrosses of heterozygotes to $\mathrm{dr} / \mathrm{dr}$ females

\begin{tabular}{|c|c|c|c|}
\hline \multirow[b]{2}{*}{$\begin{array}{l}\text { Type of family* } \\
\text { Segregation, }+: d r \\
\text { Families } \\
\chi^{2}\{\text { deviation } \\
\text { heterogeneity } \\
\text { Range of linkage values }(p \%)\end{array}$} & \multicolumn{3}{|c|}{ Sib- and inter-crosses } \\
\hline & $\begin{array}{c}\text { Excess }+ \\
523: 9^{2} \\
5 \\
33 \cdot 1[1] \\
11 \cdot 3[4] \\
9 \cdot 5-38 \cdot 5\end{array}$ & $\begin{array}{c}3: 1 \\
653: 2 \mathrm{I} 3 \\
5 \\
0 \cdot 8[1] \\
4 \cdot 5[4]\end{array}$ & $\begin{array}{l}\text { Excess } d r \\
159: 131 \\
4 \\
62 \cdot 9[1] \\
1 \cdot 3[3] \\
5 \cdot 3-20 \cdot 6\end{array}$ \\
\hline & \multicolumn{3}{|c|}{ Backcrosses } \\
\hline $\begin{array}{l}\text { Type of family } \\
\text { Segregation, }+: d r \\
\text { Families } \\
\chi^{2}\left\{\begin{array}{l}\text { deviation } \\
\text { heterogeneity } \\
\text { Range of linkage values }(p \%)\end{array}\right.\end{array}$ & $\begin{array}{c}\text { Excess }+ \\
426: 146 \\
6 \\
137 \cdot 1[1] \\
19 \cdot 9[5] \\
16 \cdot 7-40 \cdot 0\end{array}$ & $\begin{array}{c}1: 1 \\
146: 136 \\
3 \\
0 \cdot 4[1] \\
2 \cdot 8[2] \\
\end{array}$ & $\begin{array}{c}\text { Excess } d r \\
56: 214 \\
3 \\
92 \cdot 5[\mathrm{I}] \\
2: 3[2] \\
14 \cdot 6-25 \cdot 0\end{array}$ \\
\hline
\end{tabular}

* One family in each of the three types included reciprocal data; no reciprocal differences found.

Table 4 summarises observations on reciprocal comparisons: all the five possible situations were detected.

To show that all bias in droopy segregations disappears when four $S$-alleles are segregating, outcrosses of droopies were made to unrelated 
normal plants and various sib- and intercrosses were made among the progeny. Expectations are an array of families, some giving unbiased 3: I ratios, others the two possible biases but without reciprocal differences. Results (table 5) agreed with expectation. Similarly, heterozygotes were crossed as males to various compatible droopies as females. Expectations-which were also realised-are an array of families showing the two possible biases together with unbiased I:I ratios, which are impossible unless four $S$-alleles are present.

Recombination values are remarkably variable. The estimate given in table $\mathrm{I}$ ( 8.8 per cent.) theoretically needs adjustment because roughly equal numbers of normal and droopy plants were tested, rather than a random sample of the family, but the correction is in fact very small. Recombination values estimated from droopy segregation data alone are extraordinarily variable (tables 3 and 5), ranging from $2 \cdot 2$ to $44^{\cdot}$ I per cent. The best estimates (from large backcross families) mostly lie between 10 and 25 per cent.

\section{(ii) Germination bias}

The cross C.P.C. $2862 \times 2863$ was first examined because it was noticed that some seeds were germinating in the berry at harvest and the material seemed therefore to be of possible interest from the viewpoint of the physiology and genetical control of seed dormancy. The berry-germinated seeds all grew into droopies while a sample of ungerminated seeds mostly gave normals. There was therefore a suggestion of association between droopiness and premature germination. The parent clones are both members of the Group Phureja; they bear tubers and seeds having low, indeed nearly no, dormancy (Simmonds, I964) and the berry-germinating behaviour is simply an expression of this in berries harvested over-mature (i.e. 8-1o weeks old as against the standard six weeks). Care was therefore taken to harvest all berries used in this study at 6 weeks of age and families were grown from seed that was either non-dormant or had been treated with gibberellic acid; plants were raised from counted seed-lots and every seedling was grown for scoring. Bias due to association of droopiness with low dormancy was thus avoided.

Tables 6 and 7 summarise observations that prove the existence of the association. The data of table 6 show that the berry-germinating fraction in an over-mature berry consists entirely of droopies. Table 7 shows that, even when germination in the berry is not in question, droopies germinate more quickly (i.e. are less dormant) than normals. The association is probably due to a pleiotropic effect of the $d r$ gene on dormancy.

\section{CONCLUSIONS}

Three cases of linkage to the $S$-locus have previously been reported. Brieger and Mangelsdorf (1926) described reciprocal backcross data for Nicotiana sanderae, proving linkage between $S$ and $C / c$ (Coloured/green 
stem, etc.). Anderson and de Winton (193 I) gave evidence of linkage between $S$ and genes governing more or less metrical flower characters in an $F_{2}$ of Nicotiana langsdorffi $\times$ alata. Emerson (194I) found that the allele $S_{20}$ was sometimes linked to a rare pollen lethal in Oenothera

TABLE 6

Association of droopy with low dormancy: two backcross families (unbiased I:I ratios) comparing overmature berries having premature seed germination in the berry wath berries of the same crosses harvested at maturity and devoid of premature germination

\begin{tabular}{|c|c|c|c|c|}
\hline Family & Seed & $\begin{array}{l}\text { Numbers } \\
\text { of seeds }\end{array}$ & $\begin{array}{c}\text { Observed } \\
+\quad d r\end{array}$ & $\begin{array}{c}d r \\
\text { per cent. }\end{array}$ \\
\hline $64 / 173$ & $\begin{array}{l}\text { Berry overmature } \\
\quad\left\{\begin{array}{l}\text { seeds germinated } \\
\text { not }\end{array}\right. \\
\text { Berry mature, } \\
\quad \text { seeds not germinated }\end{array}$ & $\begin{array}{r}134 \\
255 \\
-\end{array}$ & $\begin{array}{rr}0 & 97 \\
53 & 18 \\
& \\
3^{6} & 3^{8}\end{array}$ & $\begin{array}{l}5 I \cdot 2 \\
5 I \cdot 4\end{array}$ \\
\hline $64 / 174$ & $\begin{array}{l}\text { Berry overmature } \\
\qquad\left\{\begin{array}{l}\text { seeds germinated } \\
\text { not }\end{array}\right. \\
\text { Berry mature, } \\
\quad \text { seeds not germinated }\end{array}$ & $\begin{array}{r}222 \\
350 \\
-\end{array}$ & $\begin{array}{rr}0 & 98 \\
74 & 13 \\
& \\
41 & 43\end{array}$ & $\begin{array}{l}47 \cdot 9 \\
5 I \cdot 2\end{array}$ \\
\hline
\end{tabular}

\section{TABLE 7}

Association of droopy with low dormancy: fresh seed treated with gibberellic acid to break dormancy, seedlings potted in order of germination and families classified into two halves $(I, 2)$ ty rate of germination

\begin{tabular}{|c|c|c|c|c|c|}
\hline Segregation type & Families & $\begin{array}{c}\text { Obs } \\
+\end{array}$ & $\begin{array}{l}\text { ved } \\
d r\end{array}$ & \multicolumn{2}{|c|}{$d r$ per cent } \\
\hline $1: 1$, unbiased & 6 & $\begin{array}{l}1.29 \\
2.117\end{array}$ & $\begin{array}{r}145 \\
24\end{array}$ & $\begin{array}{l}83 \\
17\end{array}$ & 54 \\
\hline $1: 1$, excess + & 14 & $\begin{array}{l}\text { 1.I } 74 \\
2.251\end{array}$ & $\begin{array}{r}79 \\
2\end{array}$ & $\begin{array}{r}31 \\
I\end{array}$ & I6 \\
\hline $3: 1$, excess + & 1 & $\begin{array}{l}\text { I. } 18 \\
\text { 2. } 21\end{array}$ & $\begin{array}{l}2 \\
0\end{array}$ & $\begin{array}{r}10 \\
0\end{array}$ & 5 \\
\hline $3: 1$, excess $d r$ & 2 & $\begin{array}{l}\text { I. II } \\
\text { 2. } 34\end{array}$ & $\begin{array}{l}25 \\
10\end{array}$ & $\begin{array}{l}69 \\
23\end{array}$ & 44 \\
\hline
\end{tabular}

organensis, with about 0.3 per cent. recombination. Formally, the droopy case is the most completely analysed; the only markedly aberrant feature of it is the extreme variability of recombination values.

Droopy provides the second instance known in potatoes in which an association with dormancy could lead to bias either in classification for 
genetical studies (droopy) or in selection for plant breeding purposes (association between seed- and tuber-dormancy-Simmonds, I964).

\section{SUMMARY}

A naturally-occurring recessive mutant, droopy $(d r)$, of diploid cultivated potatoes $(2 n=2 x=24$ ) was studied. Linkage to the $S$ (incompatibility) locus leads to biased $F_{2}$ and backcross ratios, together with various characteristic reciprocal differences. Recombination was remarkably variable, ranging from $2 \cdot 2$ to $44^{\circ}$ I per cent. Droopy $(d r d r)$ zygotes are less dormant than normals; this is probably a pleiotropic effect which could lead to serious bias in the classification of segregating families.

\section{REFERENCES}

ANDERSON, E., AND DE Winton, D. 1931. The genetic analysis of an unusual relationship between self-sterility and self-fertility in Nicotiana. Ann. Mo. bot. Gdn., $18,97-\mathrm{I} 16$.

BRIEGER, F. G., AND MANGELSDORF, A. J. I926. Linkage between a flower colour factor and self-sterility factors. Proc. nat. Acad. Sci. Wash., 12, 248-55.

DodDs, K. S., AND PAXMAN, G. J. I962. The genetic system of cultivated diploid. potatoes. Evolution, $16,154^{-167}$.

EMERSON, s. 1941. Linkage relationship of two gametophytic characters in Oenothera organensis. Genetics, 26, 469-473.

John InNes Institute. 1961. Potato Genetics Dep. Rep. Innes Inst., 1960, 26-35.

simmonds, N. w. 1964. The genetics of seed and tuber dormancy in the cultivated potatoes. Heredity, 19, 489-504.

simmonds, N. W. I965. Mutant expression in diploid potatoes. Heredity, 20, 65-72. WAGGONER, P. E., AND SimmonDs, N. W. 1966. Stomata and transpiration of droopy potatoes. Pl. Physiol., in press.

Note Added in Proof. The situation described here holds only for a gametophytic incompatibility system. Thompson and Taylor (Euphytica, 14, 285-92, 1965) make the point that linkage to the $S$-locus in a plant having a sporophytic system (such as Brassica) does not lead to disturbed segregation. 